\title{
APPLICATION OF THE ANALYTIC HIERARCHY PROCESS IN THE SELECTION OF STORAGE RACK SYSTEMS FOR E-COMMERCE CLOTHING INDUSTRY
}

\author{
DOI: 10.17261/Pressacademia.2018.986
}

JMML- V.5-ISS.4-2018(1)-p.255-266

\author{
Sebnem Indap \\ Maltepe University, Logistics \& Supply Chain Management PhD. Programme, Maltepe, Istanbul, Turkey. \\ sindap@gmail.com, ORCID: 0000-0003-3825-7453
}

Date Received: October 5, 2018

Date Accepted: December 11, 2018

To cite this document

Indap, S. (2018). Application of the analytic hierarchy process in the selection of storage rack systems for e-commerce clothing industry. Journal of Management, Marketing and Logistics (JMML), V.5(4), p.255-266.

Permanent link to this document: http://doi.org/10.17261/Pressacademia.2018.986

Copyright: Published by PressAcademia and limited licensed re-use rights only.

\begin{abstract}
Purpose- In this study, it was aimed to select the appropriate storage rack system for e-commerce clothing industry, by comparing storage rack systems in terms of criteria such as cost, volume utilization, height utilization, ease of order picking and stock cycle speed.

Methodology- First of all a literature review is carried out. Secondly, the comparison of the storage systems is made and the ones that are suitable for the e-commerce sector and that will be included in the AHP (Analytical Hierarchy Process) analysis are determined. Finally, a semistructured interview is done with 3 e-commerce sector representatives and the AHP method is used to analyze the data.

Findings- Considering the usage areas, features, advantages and disadvantages; it was decided to include Back-to-Back and Narrow Aisle and Automatic Storage Systems in the AHP analysis. Back-to-Back Rack System was found to be first with $36.2 \%$ ratio. Automatic Storage Systems are in the second place due to their cost disadvantage although they are advantageous for all other criteria. Narrow Aisle Rack System is in the third place, although it more cost-effective than the Automatic Storage Systems, it falls behind it in terms of other criteria, especially the inventory cycle speed criterion.

Conclusion- As a result of the study using AHP multi-criteria decision-making method, Back-to-Back Rack System was evaluated as the most suitable storage rack system for e-commerce clothing sector.
\end{abstract}

Keywords: AHP method, multi criteria decision-making, warehouse design, storage rack system selection. JEL Codes: C44, C61, L62, L81

\section{INTRODUCTION}

In today's environment, the rise of e-commerce business around the world made a tremendous change both in purchasing habits and in retail and logistics industry (Leung, Choy, Siu, Ho, Lam, \& Lee, 2018). As competition is increasing in terms of price, quality and time, warehouses provide efficiency in Supply Chain Management and play a critical role in meeting the highest customer service level at the lowest cost. Customer service and logistics costs can be improved by optimum warehouse design, proper selection and use of storage systems. Today, static or dynamic storage methods can be applied by storage on the ground, by using rack systems or automatic storage systems in which people do not enter.

Supply chains become more transparent with the developments in information and communication technology and digital transformation. Therefore supply chains enable to offer different value proposals to customers. Organizations that create a data-driven supply chain can benefit from more accurate forecasts, real-time problem identification and solutions, new segmentations, and rapid response to consumer requirements (Meerkamp, 2018). Companies can implement an omni-channel strategy that allows their customers to purchase products from a physical store or over the Internet. Products can be tracked 
throughout the supply chain. Augmented reality-based systems support a variety of services, such as selecting parts in a warehouse and sending repair instructions over mobile devices. Augmented reality glasses can enable product selection and error-free collection in the warehouse. These systems are currently in their infancy, but in the future, companies will make much broader use of augmented reality to provide workers with real-time information to improve decision-making and work procedures (Tansan, Gökbulut, Targotay, \& Eren, 2016).

The competitiveness of companies will increase by improved warehouse design and reduced delivery times with the help of smart warehouse and logistics solutions. Supply chain management is of great importance in terms of market success of companies and sustainable competition. Storage systems are also a critical component of supply chain management. The main purpose of storage systems is to enable the company to respond to customer demands and expectations rapidly and at the desired level. In accordance with this purpose, it can be said that storage facilities play an important role in the success of the supply chain (Özçakar, Görener, \& Arıkan, 2012).

The advantages and disadvantages of different storage systems such as volume utilization, efficient use of height, ease of order picking, ensuring the safety of the product, ensuring work safety and stock control should be considered in selecting the storage system suitable for product properties and processes. In this study, a model has been proposed for selecting warehouse rack system in order to support the timely and accurate delivery requirement for the e-commerce industry, which continues its development in Turkey.

As a result of the widespread use of the Internet and smart phones, e-commerce continues to grow in Turkey parallel to its global growth. The traditional single channel shopping experience is evolving to an omni-channel experience as the borders between channels are disappearing. The growth of mobile is one of the main factors triggering the transition to omni-channel. Therefore, it is necessary for traditional retailers to invest in online and digitalization to achieve sustainable success. Technology trends that eliminate the borders between offline and online, and enhance consumer experience and knowledge in numerous areas are also reshaping commerce. Technological trends such as chatbots, personalized offers, and delivery by drones will affect the near future of commerce significantly. Between the years 2013-2016 the average volume of retail e-commerce grew by $34 \%$ in Turkey and online's share in total retail sales was 3.5\% in 2016 . Compared to the world average of $8.5 \%$, Turkey still has a long way to go. With 46 million Internet users, 58\% Internet penetration and with smartphone penetration reaching $65 \%$ in 2016 , Turkey is above the world average of $60 \%$. The share of mobile e-commerce in Turkey, where smart phone penetration continues to increase rapidly, is still at $19 \%$ levels. Considering that the world average is $44 \%$, there is serious potential in Turkey; especially since smartphone penetration is above world average (Kantarcı, Özalp, Sezginsoy, Özaşkınlı, \& Cavlak, 2017).

Although online shopping trend is expected to continue, order fulfillment along supply chains is still one of the major bottlenecks that effects e-commerce (Cho, Ozment, \& Sink, 2008), (Wang, Zhan, Ruan, \& Zhang, 2014). From the consumer point of view, the most important value proposition of e-commerce for Turkish consumers is still its price advantage. In developed e-commerce markets, convenience stands out more prominently. Only one out of three customers who use the Internet in Turkey shop online. One out of four customers who shop online state that they have had problems in the postpurchase, fulfillment and return processes. For the development of the e-commerce sector, the development of Internet, logistics and payment systems infrastructures is very important. In the logistics aspect, e-commerce requires different logistical competencies than traditional retail due to changing demand, and the necessity of delivering to thousands of points in short delivery times. In the transition to e-commerce, it is essential for traditional retailers to understand and implement the necessary supply chain competencies required for processes such as planning demand, inventory, procurement, distribution, and product tracking. Fulfillment is a process greatly valued by the consumers, and one that influences their purchasing decisions. While important trends such as free delivery, same-day delivery, and synchronized tracking of the shipment should be followed, it is also necessary to deliver the customers' products completely and without damage. As the return processes are simplified, the introduction of standards to processes for encouraging trust will increase satisfaction and confidence (Kantarcl, Özalp, Sezginsoy, Özaşkınlı, \& Cavlak, 2017).

However, $23.2 \%$ of the individuals who participated in the TüiK (Turkish Statistical Institute) survey and placed an order over the Internet in the 12-month period until March 2015 stated that they had problems. $47 \%$ complained about late delivery and $45.4 \%$ complained about wrong or damaged product delivery (URL1, 2015). At this point, parcel delivery companies need to improve their processes and increase their level of integration with e-commerce companies.

Considering the purchases which require physical delivery, the use of e-commerce for fashion and entertainment is more popular in Europe. European consumers are more likely to buy clothes or shoes online (48\%), than electronic equipment (31\%) (Morganti, Seidel, Blanquart, Dablanc, \& Lenz, 2014). Similarly in Turkey, according to the TÜik survey, in the 12-month period 
between April 2016 and March 2017, 62.3\% of the individuals shopping online bought clothing and sports equipment, 21.9\% purchased food items and daily requirements and 19\% bought electronic devices (URL2, 2017).

Therefore in the scope of the study, the companies that sell clothing materials with the highest share in e-commerce were included.

In the second part of the study, the literature review is summarized. In the third chapter, the comparison of the storage systems is made and the ones that are suitable for the e-commerce sector and will be included in the AHP (Analytical Hierarchy Process) analysis are determined. In Chapter 4, the implementation of the AHP method is given. The results obtained are summarized and recommendations are indicated in Chapter 5.

\section{LITERATURE REVIEW}

A literature review was conducted with the following keywords: "AHP Method", "Multi Criteria Decision Making", "Warehouse Design" and "Storage Rack System Selection". The studies examined are classified according to their research methods and subjects in Table 1.

Articles and thesis with both of the keywords "Warehouse Design" and "AHP Method" were also examined. As a result of the examination; it has been observed that AHP, VIKOR and similar multi-criteria decision-making methods are mainly used for studies with the focus on "Warehouse Site Selection" (Aktepe \& Ersöz, 2014), "Distribution Center Site Selection" (Nişel, Coşkun, \& Timor, 2005) and "Supplier Selection" (Kahraman, Cebeci, \& Ulukan, 2003), (Falsini, Schiraldi, \& Fondi, 2012), (Büyüközkan \& Göçer, 2016), (Günay \& Özyörük, 2016), (Eren \& Gür, 2017). Also studies on “Warehouse Operator Selection” (Korpela, Lehmusvaara, \& Nisonen, 2007), “Equipment Selection" (Dağdeviren, 2008) and "Packaging Selection" (Tümenbatur, 2016) are found. When the studies on "Storage Rack Systems" are investigated, most of the studies found are related to inventory optimization as listed in Table 1 like "Order Picking" (Hwang \& Cho, 2006), (Tunç, Kutlu, Zincidi, \& Atmaca, 2008), (Ofluoğlu \& Baki, 2016) and "Shelf-Space Allocation" (Özcan, 2010), (Geismar, Dawande, Murthi, \& Sriskandarajah, 2015), (Tsaia \& Huang, 2015), (Hübner \& Schaal, 2017) .

Matson \& White (1981) focused on optimization procedures for the design and selection of storage system alternatives, including block stacking, single-deep and double-deep pallet rack, and deep lane storage. The development and application of analytical models were demonstrated for the design of storage systems based on floor space utilization and handling time criteria.

No specific study that applied "AHP method for the selection of storage rack system" was found in the literature review.

Table 1: Classification of Research

\begin{tabular}{|l|l|l|}
\hline Research & Method & Subject \\
\hline 1. (Matson \& White, 1981) & $\begin{array}{l}\text { Non-Linear Integer Programming Model, } \\
\text { Kind's Approximation Method }\end{array}$ & Storage System Optimization \\
\hline 2. (Karakış, 2014) & $\begin{array}{l}\text { AHP, } \\
\text { Hierarchical Warehouse Design Methodology }\end{array}$ & $\begin{array}{l}\text { Warehouse Design, Conventional/ } \\
\text { Automatic Warehouse Decision Problem }\end{array}$ \\
\hline 3. (Dağdeviren, 2008) & $\begin{array}{l}\text { AHP, } \\
\text { PROMETHEE (Preference Ranking Organization } \\
\text { Method For Enrichment Evaluations) }\end{array}$ & Equipment Selection \\
\hline 4. (Uztürk \& Büyüközkan, 2016) & QFD (Quality Function Deployment) & Warehouse Design \\
\hline 5. (Rosinska \& Chillara, 2017) & $\begin{array}{l}\text { Systematic Layout Planning (SLP), } \\
\text { Systematic Handling Analysis (SHA) }\end{array}$ & Warehouse Design \\
\hline 6. (Hsieh \& Tsai, 2006) & Simulation & Warehouse Design \\
\hline 7. (Yang \& Kuo, 2003) & AHP & Facilities Layout Design \\
\hline 8. (Baray \& Çakmak, 2014) & Particle Swarm Optimization Algorithm & Warehouse Layout Design \\
\hline 9. (Hwang \& Cho, 2006) & Simulation & Order Picking, Warehouse Design \\
\hline 10. (Ofluoğlu \& Baki, 2016) & Simulation, Routing & Order Picking \\
\hline 11. (Tunç, Kutlu, Zincidi, \& \& & $\begin{array}{l}\text { Steiner Travelling Salesman Problem, } \\
\text { Dynamic Programming }\end{array}$ & Order Picking \\
\hline 12. (Geismar, Dawande, Murthi, \& & MIP (Mixed Integer Programming), MWIS Shelf-Space Allocation \\
\hline
\end{tabular}




\begin{tabular}{|c|c|c|}
\hline Research & Method & Subject \\
\hline Sriskandarajah, 2015) & (Maximum Weight İndependent Set Problem) & \\
\hline 13. (Hübner \& Schaal, 2017) & MIP & Shelf-Space Allocation \\
\hline 14. (Tsaia \& Huang, 2015) & $\begin{array}{l}\text { UMSPL (High-Utility Mobile Sequential Pattern } \\
\text { by a Level-wised Method), Hungarian Method }\end{array}$ & Shelf-Space Allocation \\
\hline 15. (Özcan, 2010) & Non-Linear Integer Programming Model & Shelf-Space Allocation, Product Selection \\
\hline $\begin{array}{l}\text { 16. (Korpela, Lehmusvaara, \& } \\
\text { Nisonen, 2007) }\end{array}$ & AHP, DEA (Data Envelopment Analysis) & Warehouse Operator Selection \\
\hline 17. (Aktepe \& Ersöz, 2014) & AHP, VIKOR, MOORA & Warehouse Site Selection \\
\hline 18. (Nişel, Coşkun, \& Timor, 2005) & AHP & Distribution Center Site Selection \\
\hline 19. (Yıldırım \& Erol, 2016) & Survey, Regression Analysis & Supply Center, Facility Location Selection \\
\hline $\begin{array}{l}\text { 20. (Koska, Göksu, \& Sünbül, } \\
\text { 2016) }\end{array}$ & AHP & Green Supply Chain Management \\
\hline 21. (Eren \& Gür, 2017) & AHP, TOPSIS & $\begin{array}{l}\text { Selection of 3PL Company for Online } \\
\text { Shopping Sites }\end{array}$ \\
\hline 22. (Büyüközkan \& Göçer, 2016) & AHP, VIKOR & Logistic Firm Selection \\
\hline $\begin{array}{l}\text { 23. (Kahraman, Cebeci, \& Ulukan, } \\
\text { 2003) }\end{array}$ & AHP & Supplier Selection \\
\hline 24. (Günay \& Özyörük, 2016) & AHP, VIKOR & Supplier Selection \\
\hline $\begin{array}{l}\text { 25. (Falsini, Schiraldi, \& Fondi, } \\
\text { 2012) }\end{array}$ & AHP, DEA, Linear Programming & Supplier Evaluation and Selection \\
\hline 26. (Tümenbatur, 2016) & AHP & Packaging Selection \\
\hline
\end{tabular}

\section{COMPARISON OF STORAGE SYSTEMS}

In the warehouse design process, while selecting the storage system that is suitable for the product specifications and processes, the advantages and disadvantages of storage systems should be evaluated in terms of volume and height utilization, ease of order picking, ensuring product safety and stock control (Karakış, 2014).

In this section, the properties of storage systems will be examined and those who are considered to be unsuitable for the ecommerce clothing sector will be eliminated before starting the AHP analysis. In addition to general advantages, criteria like height-volume efficiency, product variety, stock cycle speed and compliance with FIFO (First In First Out) method, which are more important for warehouse management in e-commerce clothing sector will be taken into consideration. AHP analysis will be performed for the storage systems that are considered appropriate after the pre-evaluation.

Storage systems can be classified as ground storage, shelves and automatic storage systems. If ground storage is used, goods are stored directly on the floor and stacked, if necessary. Goods can be stored in shelves, mostly by means of a loading aid. Racks are used to optimally utilize the space and height of warehouses (Hompel \& Schmidt, 2005). Racks can also be classified as short or medium span shelving, over-rack platforms, high-rise shelving, multi-storey and mobile shelving (Tanyaş, 2017).

Appendix 1 shows respectively the features of ground storage, shelf/rack storage and automatic storage systems, which are suitable and unsuitable for the e-commerce clothing industry. And accordingly the rack systems that will and won't be included in the AHP analysis are determined.

Considering the usage areas, features, advantages and disadvantages; ground storage systems will not be included in the AHP analysis since they are not suitable for e-commerce clothing industry. It was decided to include Back-to-Back and Narrow Aisle storage systems in the AHP analysis. Despite the high installation and maintenance-repair costs, as e-commerce companies have a wide variety of product stocks and high stock circle speed, it has been decided to consider the automatic storage systems in the AHP analysis.

Table 2 shows the comparison table for storage systems (Tanyaş, 2017). While the features such as load accessibility, order picking and load balance are at the highest level for the Back-to-Back, Narrow Aisle and Automatic Storage Systems - which are decided to be included in the AHP analysis as a result of the preliminary evaluation in Appendix 1 - it is seen that they have differences in terms of volume utilization, height utilization and stock cycle speed. In the AHP analysis, considering Back-to-Back, 
Narrow Aisle and Automatic Storage Systems, it will be tried to determine the most suitable storage system for the e-commerce clothing sector in terms of cost, volume utilization, height utilization, load accessibility and stock cycle speed criteria.

Table 2: Comparison of Storage Systems (Tanyaş, 2017)

\begin{tabular}{|l|l|l|l|l|l|l|l|l|}
\hline Features & $\begin{array}{l}\text { Ground } \\
\text { Storage }\end{array}$ & $\begin{array}{l}\text { Back-to- } \\
\text { Back }\end{array}$ & $\begin{array}{l}\text { Double } \\
\text { Deep }\end{array}$ & $\begin{array}{l}\text { Narrow } \\
\text { Aisle }\end{array}$ & Drive-In & $\begin{array}{l}\text { Drive-In } \\
\text { Satellite }\end{array}$ & Mobile & AS/RS \\
\hline Volume Utilization & $\% 65$ & $\% 45$ & $\% 55$ & $\% 57$ & $\% 65$ & $\% 85$ & $\% 80$ & $\% 62$ \\
\hline Height Utilization & $\% 75$ & $\% 100$ & $\% 80$ & $\% 100$ & $\% 75$ & $\% 90$ & $\% 70$ & $\% 95$ \\
\hline Load Accessibility & $\% 10$ & $\% 100$ & $\% 50$ & $\% 100$ & $\% 30$ & $\% 50$ & $\% 50$ & $\% 100$ \\
\hline Order Picking & $\% 5$ & $\% 100$ & $\% 40$ & $\% 100$ & $\% 30$ & $\% 30$ & $\% 30$ & $\% 100$ \\
\hline Risk of Physical Damage & $\% 3$ & $\% 0,2$ & $\% 0,3$ & $\% 0,2$ & $\% 1$ & $\% 0,2$ & $\% 0,5$ & $\% 0,1$ \\
\hline Load Balance & $\% 90$ & $\% 100$ & $\% 100$ & $\% 100$ & $\% 99$ & $\% 100$ & $\% 95$ & $\% 100$ \\
\hline Stock Control & $\% 0$ & $\% 95$ & $\% 70$ & $\% 95$ & $\% 70$ & $\% 70$ & $\% 70$ & $\% 100$ \\
\hline Stock Cycle Speed & $\% 0$ & $\% 60$ & $\% 40$ & $\% 70$ & $\% 40$ & $\% 90$ & $\% 100$ & $\% 95$ \\
\hline
\end{tabular}

\section{METHODOLOGY AND THE APPLICATION}

\subsection{The Analytical Hierarchy Process (AHP) Method}

The Analytical Hierarchy Process (AHP) is one of the multi-criteria decision-making techniques developed by Thomas L. Saaty in 1977. AHP is an easily understandable and implementable method, which enables the determination of the criteria priorities and the evaluation of alternatives based on these determined priorities (Günay \& Özyörük, 2016). The AHP is a mathematical technique, which assesses quantitative and qualitative variables that takes into account the priorities of the individual or the group in the decision-making process (Dağdeviren, Akay, \& Kurt, 2004). The problem in AHP is structured in a hierarchical manner. As shown in Figure 1, the goal is at the top of the hierarchy and the structure is completed in such a way that the criteria and the alternatives are at the bottom (Ömürbek \& Tunca, 2013).

Figure 1: Three Levels Analytical Hierarchy Model (Ömürbek \& Tunca, 2013)

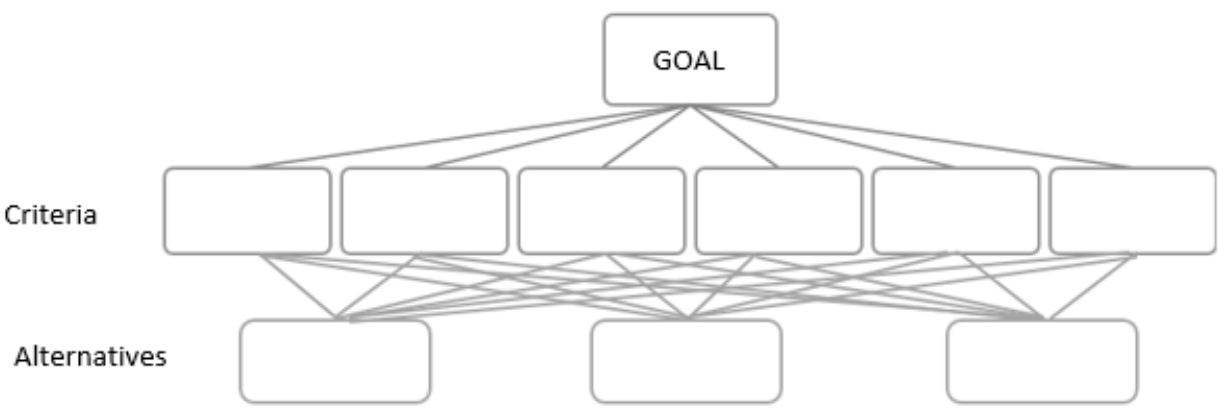

When applying the AHP analysis, first the problem is identified, and then the problem is separated into a hierarchy of goal, criteria, sub-criteria and alternatives. The goal of creating a hierarchical framework is the estimation of the level of influence of elements in the upper level on the elements in the lower levels. In the second step, pairwise comparison matrixes are constructed to determine the significance levels between the criterion and the sub-criteria. Decision makers compare criteria and alternatives in pairs using 1-9 point scale. If there is more than one decision maker, the averages of the evaluations can be taken.

The pairwise comparison matrix is a square matrix of $\mathrm{n} \times \mathrm{n}$ dimensions. The components on the diagonal of the comparison matrix, i.e., when $i=j$, take the value of 1 . The comparisons are made for values above the diagonal whose value is 1 . For components remaining below the diagonal, the formula (1) is used. 
$a_{j i}=\frac{1}{a_{i j}}$

In the third step, the formula (2) is used to calculate the eigenvector, which shows the relative importance of each item in relation to the other items.

$b_{i j}=\frac{a_{i j}}{\sum_{i=1}^{n} a_{i j}}$

When $\mathrm{n}$ number of $\mathrm{B}$ column vectors are combined in a matrix format, a matrix $\mathrm{C}$ is formed. The weights of the criterion are calculated as shown in equation (3).

$w_{i}=\frac{\sum_{j=1}^{n} c_{i j}}{n}$

The weights of the alternatives are multiplied with the weights of the criteria and overall weighted priority is summed to calculate the priority value of each alternative. The highest value alternative is the best alternative for the decision problem. Finally, the consistency ratio is calculated for each comparison matrix. The upper limit for this ratio is expected to be 0.1 . If the ratio is greater than 0.1 , it indicates that the decision maker has inconsistencies in the judgments and that the judgments should be improved (Büyüközkan \& Göçer, 2016).

\subsection{Application}

The AHP model used in the selection of the storage rack system for the e-commerce clothing industry is shown in Figure 2.

Figure 2: Hierarchical Structure of Storage Rack System Selection for E-Commerce Clothing Industry

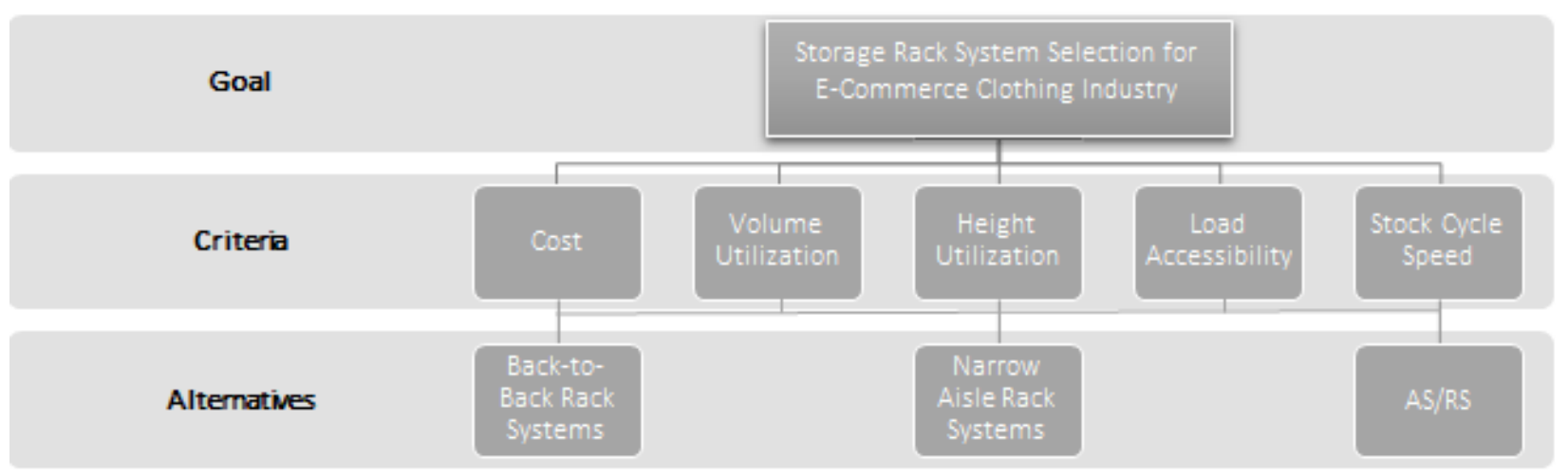

The average of the five main criteria assessed by 3 managers in the e-commerce sector is shown in Table 3. Table 4 shows the normalized values of the averaged values of the criteria by the formula (2) and the weights calculated by the formula (3). The consistency ratio was calculated as 0.075 , which is below 0.1 proving the consistency. It is seen that the stock cycle speed and load accessibility criteria have a higher share than the other criteria for the storage rack system to be selected. 
Table 3: Average of Main Criteria Assessments

\begin{tabular}{|l|l|l|l|l|l|}
\hline MAIN CRITERIA & Cost & $\begin{array}{l}\text { Volume } \\
\text { Utilization }\end{array}$ & Height Utilization & Load Accessibility & Stock Cycle Speed \\
\hline Cost & 1 & 2 & 3,667 & 0,333 & 0,289 \\
\hline Volume Utilization & 0,500 & 1 & 2,667 & 0,244 & 0,225 \\
\hline Height Utilization & 0,273 & 0,375 & 1 & 0,289 & 0,333 \\
\hline Load Accessibility & 3 & 4,091 & 3,462 & 1 & 1,667 \\
\hline Stock Cycle Speed & 3,462 & 4,437 & 3 & 0,600 & 1 \\
\hline
\end{tabular}

Table 4: Normalized Values and Weights of Main Criteria

\begin{tabular}{|l|l|l|l|l|l|l|}
\hline Normalized Values & Cost & $\begin{array}{l}\text { Volume } \\
\text { Utilization }\end{array}$ & $\begin{array}{l}\text { Height } \\
\text { Utilization }\end{array}$ & $\begin{array}{l}\text { Load } \\
\text { Accessibility }\end{array}$ & $\begin{array}{l}\text { Stock } \\
\text { Speed }\end{array}$ & Cycle \\
\hline Cost & 0,121 & 0,168 & 0,266 & 0,135 & 0,082 & $15 \%$ \\
\hline Volume Utilization & 0,061 & 0,084 & 0,193 & 0,099 & 0,064 & $10 \%$ \\
\hline Height Utilization & 0,033 & 0,032 & 0,072 & 0,117 & 0,095 & $7 \%$ \\
\hline Load Accessibility & 0,364 & 0,344 & 0,251 & 0,405 & 0,474 & $37 \%$ \\
\hline Stock Cycle Speed & 0,420 & 0,373 & 0,217 & 0,243 & 0,285 & $31 \%$ \\
\hline
\end{tabular}

Table 5 shows the average and weight of storage rack systems according to cost criterion. The Back-to-Back Rack System with a weight of $69 \%$ is advantageous in terms of cost compared to the Narrow Aisle and Automatic Storage Systems.

Table 5: Storage Rack Systems Weights in Terms of Cost Criterion

\begin{tabular}{|c|c|c|c|c|c|c|c|c|}
\hline Cost & Back-to-Back & Narrow Aisle & AS/RS & Normalized & $\begin{array}{l}\text { Back-to- } \\
\text { Back }\end{array}$ & Narrow Aisle & AS/RS & Weights \\
\hline Back-to-Back & 1 & 3 & 9 & Back-to-Back & 0,692 & 0,692 & 0,692 & $69 \%$ \\
\hline Narrow Aisle & 0,333 & 1 & 3 & Narrow Aisle & 0,231 & 0,231 & 0,231 & $23 \%$ \\
\hline AS/RS & 0,111 & 0,333 & 1 & AS/RS & 0,077 & 0,077 & 0,077 & $8 \%$ \\
\hline
\end{tabular}

Table 6 shows the average and weight of storage rack systems according to the volume utilization criterion. Automatic Storage Systems are calculated to have higher volume utilization with a ratio of $38.5 \%$. Although Back-to-Back Rack System is advantageous in terms of cost, it is calculated to have the minimum volume utilization with a weight of $27.2 \%$.

Table 6: Storage Rack Systems Weights in Terms of Volume Utilization Criterion

\begin{tabular}{|c|c|c|c|c|c|c|c|c|}
\hline Volume Utilization & Back-to-Back & Narrow Aisle & AS/RS & Normalized & \begin{tabular}{|l} 
Back-to- \\
Back \\
\end{tabular} & Narrow Aisle & AS/RS & Weights \\
\hline Back-to-Back & 1 & 0,8 & 0,7 & Back-to-Back & 0,272 & 0,275 & 0,269 & $27,2 \%$ \\
\hline Narrow Aisle & 1,250 & 1 & 0,9 & Narrow Aisle & 0,340 & 0,344 & 0,346 & $34,3 \%$ \\
\hline AS/RS & 1,429 & 1,111 & 1 & AS/RS & 0,388 & 0,382 & 0,385 & $38,5 \%$ \\
\hline
\end{tabular}

Table 7 shows the average and weight of storage rack systems according to the height utilization criterion. It is seen that Automatic Storage Systems are advantageous compared to Back-to-Back and Narrow Aisle Rack Systems with a weight of 35\%.

Table 7: Storage Rack Systems Weights In Terms Of Height Utilization Criterion

\begin{tabular}{|c|c|c|c|c|c|c|c|c|}
\hline Height Utilization & Back-to-Back & Narrow Aisle & AS/RS & Normalized & $\begin{array}{l}\text { Back-to- } \\
\text { Back }\end{array}$ & Narrow Aisle & AS/RS & Weights \\
\hline Back-to-Back & 1 & 1 & 0,9 & Back-to-Back & 0,321 & 0,328 & 0,316 & $32 \%$ \\
\hline Narrow Aisle & 1 & 1 & 0,95 & Narrow Aisle & 0,321 & 0,328 & 0,333 & $33 \%$ \\
\hline AS/RS & 1,111 & 1,053 & 1 & AS/RS & 0,357 & 0,345 & 0,351 & $35 \%$ \\
\hline
\end{tabular}


Table 8 shows the average and weight of storage rack systems according to the load accessibility criterion. It was calculated that the load accessibility in Automatic Storage Systems is easier than the other storage rack systems, with a weight of $35 \%$.

Table 8: Storage Rack Systems Weights In Terms Of Load Accessibility Criterion

\begin{tabular}{|c|c|c|c|c|c|c|c|c|}
\hline Load Accessibility & Back-to-Back & Narrow Aisle & AS/RS & Normalized & $\begin{array}{l}\text { Back-to- } \\
\text { Back }\end{array}$ & Narrow Aisle & AS/RS & Weights \\
\hline Back-to-Back & 1 & 1,125 & 0,95 & Back-to-Back & 0,340 & 0,348 & 0,333 & $34 \%$ \\
\hline Narrow Aisle & 0,889 & 1 & 0,9 & Narrow Aisle & 0,302 & 0,309 & 0,316 & $31 \%$ \\
\hline AS/RS & 1,053 & 1,111 & 1 & AS/RS & 0,358 & 0,343 & 0,351 & $35 \%$ \\
\hline
\end{tabular}

Table 9 shows the average and weight of storage rack systems according to the stock cycle speed, which is the last criterion. Here, the highest share of $43 \%$ of the Automatic Storage Systems shows that AS/RS are advantageous in this criterion.

Table 9: Storage Rack Systems Weights In Terms Of Stock Cycle Speed Criterion

\begin{tabular}{|c|c|c|c|c|c|c|c|c|}
\hline Stock Cycle Speed & Back-to-Back & Narrow Aisle & AS/RS & Normalized & $\begin{array}{l}\text { Back-to- } \\
\text { Back }\end{array}$ & Narrow Aisle & AS/RS & Weights \\
\hline Back-to-Back & 1 & 0,85 & 0,6 & Back-to-Back & 0,260 & 0,259 & 0,261 & $26 \%$ \\
\hline Narrow Aisle & 1,176 & 1 & 0,7 & Narrow Aisle & 0,306 & 0,305 & 0,304 & $31 \%$ \\
\hline AS/RS & 1,667 & 1,429 & 1 & AS/RS & 0,434 & 0,436 & 0,435 & $43 \%$ \\
\hline
\end{tabular}

Table 10 shows the results of Back-to-Back, Narrow Aisle and Automatic Storage Systems calculated according to five main criteria. As shown in the table, Back-to-Back Rack System is the first with $36.2 \%$ ratio. Automatic Storage Systems are in the second place due to their cost disadvantage although they are advantageous for all other criteria. Narrow Aisle Rack System is in the third place, although it more cost-effective than the Automatic Storage Systems, it falls behind it in terms of other criteria, especially the inventory cycle speed criterion.

\section{Table 10: Results}

\begin{tabular}{|c|c|c|c|c|c|c|}
\hline Criteria & Cost & Volume Utilization & Height Utilization & Load Accessibility & Stock Cycle Speed & \\
\hline Weights & 0,155 & 0,100 & 0,070 & 0,368 & 0,308 & \\
\hline \multicolumn{6}{|l|}{ Alternatives } & RESULT \\
\hline Back-to-Back & 0,692 & 0,272 & 0,322 & 0,340 & 0,260 & $36,2 \%$ \\
\hline Narrow Aisle & 0,231 & 0,343 & 0,327 & 0,309 & 0,305 & $30,0 \%$ \\
\hline AS/RS & 0,077 & 0,385 & 0,351 & 0,351 & 0,435 & $33,8 \%$ \\
\hline
\end{tabular}

\section{CONCLUSION AND RECOMMENDATIONS}

In today's competitive conditions, warehouses are a crucial part of supply chains. In parallel with the developments in technology, customer expectations especially in e-commerce sector are increasing. In order to meet the small orders placed on the Internet, high service levels and fast and error-free delivery, e-commerce warehouse storage rack systems should also allow for fast and accurate picking and delivery. With the aim of increasing the order picking efficiency, fast moving products should be stored close to each other; the pallets should be divided into boxes or smaller quantities and stored near the order preparation area. E-commerce storage rack systems should allow for storage of many small parts.

This study was conducted to show the applicability of AHP method in the selection of storage rack system for e-commerce clothing sector. In this study, first of all three storage rack systems which are suitable for e-commerce sector and which will be included in AHP analysis were determined. The most important criteria in the choice of storage rack system for the e-commerce clothing sector, where speed and customer service level are important, are volume utilization, height utilization, load accessibility and stock cycle speed. In AHP analysis, five main criteria were used, including the cost criterion which is important for the sustainability of any firm. The consistency ratios for the defined criteria were calculated to be below 0.1 which indicates 
the applicability of the study. AHP analysis was carried out by taking the opinions of 3 sector representatives. More effective results can be obtained by increasing the number of sector representatives and also by taking the opinions of academicians.

\section{ACKNOWLEDGEMENT}

This study was carried out with support by Prof. Dr. Mehmet Tanyaş. His support is gratefully acknowledged.

\section{REFERENCES}

Aktepe, A., Ersöz, S. (2014). Application of AHP-VIKOR and MOORA methods in warehouse site selection problem. Endüstri Mühendisliği Dergisi(25), 2-15.

Baray, S., Çakmak, E. (2014). Design methodology for a multiple-level warehouse layout based on particle swarm optimization algorithm. İstanbul Üniversitesi İşletme Fakültesi İşletme İktisadı Enstitüsü Yönetim Dergisi(77), 13-38.

Büyüközkan, G., Göçer, F. (2016). Logistic firm selection for medical waste management. 5th. National Logistics And Supply Chain Congress (pp. 837-844). Mersin: Toros Üniversitesi.

Cho, J., Ozment, J., Sink, H. (2008). Logistics capability, logistics outsourcing and firm performance in an e-commerce market. International Journal Of Physical Distribution And Logistics Management, 336-359.

Dağdeviren, M. (2008). Decision making in equipment selection: an integrated approach with AHP and PROMETHEE. Journal of Intelligent Manufacturing(19), 397-406.

Dağdeviren, M., Akay, D., Kurt, M. (2004). Analytical hierarchy process for job evaluation and application. Journal of Gazi University Engineering And Architecture Faculty(19), 131-138.

Eren, T., Gür, S. (2017). Selection of 3PL company for online shopping sites with AHP and TOPSIS method. Hitit Üniversitesi Sosyal Bilimler Enstitüsü Dergisi(2), 819-834.

Falsini, D., Schiraldi, M., Fondi, F. (2012). A logistics provider evaluation and selection methodology based on AHP, DEA and linear programming integration. International Journal of Production Research(17), 4822-4829.

Geismar, H., Dawande, M., Murthi, B., Sriskandarajah, C. (2015). Maximizing revenue through two-dimensional shelf-space allocation. Production and Operations Management Society(24), 1148-1163.

Günay, S., Özyörük, B. (2016). Green supplier selection based on AHP \& VIKOR methods and an application. 5th. National Logistics And Supply Chain Congress (pp. 348-357). Mersin: Toros Üniversitesi.

Hompel, M., Schmidt, T. (2005). Warehouse management - automation and organisation of warehouse and order picking systems. Dortmund: Springer.

Hsieh, L., Tsai, L. (2006). The optimum design of a warehouse system on order picking efficiency. International Journal of Advanced Manufacturing Technology(28), 626-637.

Hübner, A., Schaal, K. (2017). Effect of replenishment and backroom on retail shelf-space planning. Springer Busineness Research(10), 123-156.

Hwang, H., Cho, G. (2006). A performance evaluation model for order picking warehouse design. Computers \& Industrial Engineering(51), 335342.

Kahraman, C., Cebeci, U., Ulukan, Z. (2003). Multi criteria supplier selection using fuzzy AHP. Logistics Information Management(16), $382-394$.

Kantarcı, Ö., Özalp, M., Sezginsoy, C., Özaşkınlı, O., Cavlak, C. (2017). The new growth engine in the digital world: e-commerce. İstanbul: TÜsiAD.

Karakış, i. (2014). Hierarchical warehouse design methodology and an analytical model for conventional/automatic warehouse decision problem for distribution centers. İstanbul: İstanbul Teknik Üniversitesi - Industrial Engineering Department - PhD. Thesis.

Korpela, J., Lehmusvaara, A., Nisonen, J. (2007). Warehouse operator selection by combining AHP and DEA methodologies. International Journal of Production Economics(108), 135-142.

Koska, A., Göksu, N., Sünbül, M. (2016). Barriers of green supply chain management implementation: an application in Kipaş paper factory. 5th. National Logistics And Supply Chain Congress (pp. 367-379). Mersin: Toros Üniversitesi. 
Leung, K., Choy, K., Siu, P., Ho, G., Lam, H., Lee, C. (2018). A B2C e-commerce intelligent system for re-engineering the order fulfilment process. Expert Systems With Applications, 386-401.

Matson, J., White, J. (1981). Storage system optimization. Atlanta: Georgia Instititute of Technology, Production and Distribution Research Center.

Meerkamp, F. (2018). Reinventing the supply chain with intelligent technology. Supply Chain Management Review.

Morganti, E., Seidel, S., Blanquart, C., Dablanc, L., Lenz, B. (2014). The impact of e-commerce on final deliveries: alternative parcel delvery services in France and Germany. Transportation Research Procedia, 178-190.

Nişel, S., Coşkun, E., Timor, M. (2005). Evaluating site selection factors for a main cargo distribution center using analytic hierarchy process (AHP). 3rd. International Logistics And Supply Chain Congress (pp. 592-599). İstanbul: Galatasaray University.

Ofluoğlu, A., Baki, B. (2016). Analysis of order picking process: application of a company in food distribution sector. 5th. National Logistics And Supply Chain Congress (pp. 504-511). Mersin: Toros Üniversitesi.

Ömürbek, N., Tunca, M. (2013). A case study on group decision making stage in analytic hierarchy process and analytic network process methods. Suleyman Demirel University The Journal of Faculty of Economics and Administrative Sciences(18), 47-70.

Özcan, T. (2010). Retail shelf space management: literature review and the design of a decision support tool. Yönetim(67), 84-103.

Özçakar, N., Görener, A., Arıkan, V. (2012). Optimization of order picking operations with genetic algorithms in warehouse systems. Yönetim: İstanbul Üniversitesi İşletme İktisadı Enstitüsü Dergisi(71), 118-144.

Rosinska, M., Chillara, N. (2017). Layout design planning of a logistics center: a study on space utilization after merger of two warehouses. Göteborg: Chalmers University of Technology, Department of Technology Management and Economics, Division of Supply and Operations Management, Master of Science Thesis.

Tansan, B., Gökbulut, A., Targotay, Ç., Eren, T. (2016). Industry 4.0 in Turkey as an imperative for global competitiveness - an emerging market perspective. İstanbul: TÜsiAD.

Tanyaş, M. (2017). Logistics and supply chain management PhD. Programme - Warehouse Management Lecture Notes. Istanbul: Maltepe University.

Tsaia, C., Huang, S. (2015). A data mining approach to optimise shelf space allocation in consideration of customer purchase and moving behaviours. International Journal of Production Research(53), 850-866.

Tunç, S., Kutlu, B., Zincidi, A., Atmaca, E. (2008). Improvement of order picking process in warehouse system. Gazi Üniversitesi Mühendislik Mimarlık Fakültesi Dergisi(23), 357-364.

Tümenbatur, A. (2016). Packaging selection model for fresh vegetable and fruit products: Cherry application. All Product, Container and Packaging Standards Symposium - Vegetables \& Fruits (pp. 31-37). İstanbul: TÜRKAS.

URL1. (2015, 08 18). Household information technology usage survey, $2015 . \quad$ Retrieved from TÜiK: http://www.tuik.gov.tr/PreHaberBultenleri.do?id=18660

URL2. (2017, 08 18). Household information technology usage survey, 2017. Retrieved from TÜik: http://www.tuik.gov.tr/PreHaber Bultenleri.do?id=24862

Uztürk, D., Büyüközkan, G. (2016). A QFD approach for sustainable warehouse design. XIV. International Logistics and Supply Chain Congress (pp. 257-265). İzmir: Ege University.

Wang, X., Zhan, L., Ruan, J., Zhang, J. (2014). How to choose "Last-Mile" delivery modes for e-fulfillment. Mathematical Problems In Engineering, $1-11$.

Yang, T., Kuo, C. (2003). A hierarchical AHP/DEA methodology for the facilities layout design problem. European Journal of Operational Research(147), 128-136.

Yıldırım, O., Erol, S. (2016). An application for the determination of supply center site selection criteria. 5th. National Logistics And Supply Chain Congress (pp. 845-854). Mersin: Toros Üniversitesi. 


\section{APPENDICES}

\section{Appendix 1: Preliminary Assessment of Storage Systems for E-Commerce Sector Use}

\begin{tabular}{|c|c|c|c|}
\hline System & $\begin{array}{l}\text { Suitable Properties for } \\
\text { E-Commerce Clothing Industry }\end{array}$ & $\begin{array}{l}\text { Unsuitable Properties for } \\
\text { E-Commerce Clothing Industry }\end{array}$ & $\begin{array}{l}\text { Preliminary } \\
\text { Assessment }\end{array}$ \\
\hline \multicolumn{4}{|c|}{ GROUND STORAGE SYSTEMS } \\
\hline Honey Combing & $\begin{array}{l}\text { - No need for high investment in warehouse } \\
\text { equipment } \\
\text { - Inexpensive storage of large quantities of a few } \\
\text { articles }\end{array}$ & - Low height and volume utilization & $\begin{array}{l}\text { Won't be included } \\
\text { in the AHP analysis }\end{array}$ \\
\hline Storage in Tank/Silo & & $\begin{array}{l}\text { - Used for the storage of fluid materials, liquids } \\
\text { and gases }\end{array}$ & $\begin{array}{l}\text { Won't be included } \\
\text { in the AHP analysis }\end{array}$ \\
\hline \multicolumn{4}{|c|}{ RACK STORAGE SYSTEMS } \\
\hline Back To Back & $\begin{array}{l}\text { - Economic } \\
\text { - Efficient use of vertical volume } \\
\text { - Suitable for pallet stacking } \\
\text { - Direct access to all product types } \\
\text { - Applicability of FIFO principle } \\
\text { - Use with manual or automatic stacking } \\
\text { machines }\end{array}$ & - Racked area, around $35-40 \%$ of the total area & $\begin{array}{l}\text { Will be included in } \\
\text { the AHP analysis }\end{array}$ \\
\hline Double Deep & - Wimilar features with Back-to-Back Rack System & $\begin{array}{l}\text { - Applicability of LIFO (Last In First Out) on the } \\
\text { basis of shelf-cells } \\
\text { - Additional investment requirement for } \\
\text { extension fork machines as addition to stackers } \\
\text { - Usable if the storage requirement for a Stock } \\
\text { Keeping Unit is } 5 \text { pallets or more, and if the } \\
\text { pallets move in pairs during the acceptance } \\
\text { and picking of goods }\end{array}$ & $\begin{array}{l}\text { Won't be included } \\
\text { in the AHP analysis } \\
\end{array}$ \\
\hline Narrow Aisle & $\begin{array}{l}\text { - Ideal for companies with a large assortment of } \\
\text { articles and high stock cycle speed } \\
\text { - Minimizing the risk of excessive and insufficient } \\
\text { storage }\end{array}$ & $\begin{array}{l}\text { - The need for narrow aisle stacking machines, } \\
\text { which are more expensive, for goods storage } \\
\text { and unloading }\end{array}$ & $\begin{array}{l}\text { Will be included in } \\
\text { the AHP analysis }\end{array}$ \\
\hline Single Bin & $\begin{array}{l}\text { - Similar features with Back-to-Back Rack System } \\
\text { - Only one unit load/pallet is stackable between } \\
\text { the rack supports }\end{array}$ & $\begin{array}{l}\text { - System used for the storage of heavy-content } \\
\text { products at high altitude } \\
\text { - Usually suitable for storage of products stacked } \\
\text { in crate or cage pallets }\end{array}$ & $\begin{array}{l}\text { Won't be included } \\
\text { in the AHP analysis }\end{array}$ \\
\hline Drive In & - Warehouse usage area can rise to $50 \%-60 \%$ & $\begin{array}{l}\text { - Requires a LIFO principle since the unit loads } \\
\text { are stored and retrieved at the same side } \\
\text { - Suitable for the storage of seasonal product } \\
\text { with slow or moderate stock cycle speed } \\
\text { - Occupational Safety Risk }\end{array}$ & $\begin{array}{l}\text { Won't be included } \\
\text { in the AHP analysis }\end{array}$ \\
\hline Drive Through & $\begin{array}{l}\text { - FIFO principle is applicable since the units are } \\
\text { stored and retrieved on opposite sides } \\
\text { - Suitable for companies with high stock cycle } \\
\text { speed }\end{array}$ & Occupational Safety Risk & $\begin{array}{l}\text { Won't be included } \\
\text { in the AHP analysis }\end{array}$ \\
\hline Drive in Satellite & $\begin{array}{l}\text { - Semi-automatic warehouse rack system } \\
\text { - Warehouse usage area can rise to } 85 \%\end{array}$ & $\begin{array}{l}\text { - Applicability of FILO (First In Last Out) principle } \\
\text { on each loading floor, and FIFO is theoretically } \\
\text { possible in the same loading floor if both sides } \\
\text { are accessible } \\
\text { - Suitable for storage of cold products in } \\
\text { unmanned environments }\end{array}$ & $\begin{array}{l}\text { Won't be included } \\
\text { in the AHP analysis }\end{array}$ \\
\hline Flow Rack & $\begin{array}{l}\text { - FIFO principle applicable for any size of } \\
\text { packages } \\
\text { - Warehouse usage area can rise to } 50 \%-60 \%\end{array}$ & $\begin{array}{l}\text { - Suitable for sequential package and order } \\
\text { picking for any size of products and storage of } \\
\text { small parts } \\
\text { - Suitable for small markets }\end{array}$ & $\begin{array}{l}\text { Won't be included } \\
\text { in the AHP analysis }\end{array}$ \\
\hline Push Back & - FIFO principle applicable for any size of & - Suitable for use with large volume and heavy & Won't be included \\
\hline
\end{tabular}




\begin{tabular}{|c|c|c|c|}
\hline System & $\begin{array}{l}\text { Suitable Properties for } \\
\text { E-Commerce Clothing Industry }\end{array}$ & $\begin{array}{l}\text { Unsuitable Properties for } \\
\text { E-Commerce Clothing Industry }\end{array}$ & $\begin{array}{l}\text { Preliminary } \\
\text { Assessment }\end{array}$ \\
\hline & $\begin{array}{l}\text { packages } \\
\text { - Warehouse usage area can rise to } 50 \%-60 \%\end{array}$ & $\begin{array}{l}\text { goods } \\
\text { - } 4-6 \text { rows of pallets can be placed sequentially }\end{array}$ & in the AHP analysis \\
\hline $\begin{array}{l}\text { Order Preparation/ } \\
\text { Picking }\end{array}$ & $\begin{array}{l}\text { - Low installation cost } \\
\text { - Easy to install and rearrange } \\
\text { - Suitable for stocked, boxed or unpacked } \\
\text { products which are stored unpalleted }\end{array}$ & $\begin{array}{l}\text { - More space utilization on the floor, suitable for } \\
\text { use in order preparation area } \\
\text { - Requirement of more labor force than other } \\
\text { systems } \\
\text { - Low product safety }\end{array}$ & $\begin{array}{l}\text { Won't be included } \\
\text { in the AHP analysis }\end{array}$ \\
\hline Mezzanine & $\begin{array}{l}\text { - Efficient usage of overhead volume } \\
\text { - A system that creates additional space in case } \\
\text { different floor locations are required } \\
\text { depending on product type or movement } \\
\text { density }\end{array}$ & $\begin{array}{l}\text { - Suitable for spare parts storage where there } \\
\text { are large number of small products } \\
\text { - Especially used in automotive, electrical } \\
\text { appliances, white goods sectors and their } \\
\text { supply industries }\end{array}$ & $\begin{array}{l}\text { Won't be included } \\
\text { in the AHP analysis }\end{array}$ \\
\hline Gargamel & & $\begin{array}{l}\text { - Used for the storage of long goods such as } \\
\text { carpets, parquet, profiles, pipes, plastics, etc. }\end{array}$ & $\begin{array}{l}\text { Won't be included } \\
\text { in the AHP analysis }\end{array}$ \\
\hline $\begin{array}{l}\text { Rack Clad Building } \\
\text { Systems }\end{array}$ & $\begin{array}{l}\text { - Lower building cost less } \\
\text { - Easier and shorter production and installation } \\
\text { process }\end{array}$ & $\begin{array}{l}\text { - Eliminates the roof and exterior siding needs of } \\
\text { the warehouse } \\
\text { - Roof and exterior siding of the warehouse can } \\
\text { be built on the shelves } \\
\text { - No flexibility after installation }\end{array}$ & $\begin{array}{l}\text { Won't be included } \\
\text { in the AHP analysis }\end{array}$ \\
\hline Mobile & - Warehouse usage area can rise to $80 \%$ & $\begin{array}{l}\text { - Limited product accessibility } \\
\text { - Not suitable for fast moving products, suitable } \\
\text { for archive warehouses } \\
\text { - High investment requirement for warehouse } \\
\text { equipment }\end{array}$ & $\begin{array}{l}\text { Won't be included } \\
\text { in the AHP analysis }\end{array}$ \\
\hline \begin{tabular}{|l|} 
Conveyor/Rack \\
Systems With \\
Hangers
\end{tabular} & $\begin{array}{l}\text { Suitable for some of the Garment (Ready-to- } \\
\text { Wear) products }\end{array}$ & - Suitable only for hanging products & $\begin{array}{l}\text { Won't be included } \\
\text { in the AHP analysis }\end{array}$ \\
\hline \multicolumn{4}{|c|}{ AUTOMATIC STORAGE SYSTEMS } \\
\hline
\end{tabular}

